\title{
Arachnoid Mater
}

unforgettable but

beyond

recollection

a single sanguine sample

declares its delinquency

dolor rubor

the fulmination inside her head

crimson crawling along her silken web

wracking nerves

a family waits, wonders, and bargains

inside, strangers purport to understand

humans and their humours they hope

anatomy, capricious as it is, will now

permit them entry

anaesthesia standing by, Neith reminds them yet again

a moment astray and the web is unwound

they bate their breaths so that she may breathe

\section{Adam A Dmytriw}

Correspondence to Adam A Dmytriw, MD MSc, Department of Medical Imaging, University of Toronto, 263 McCaul Street, Toronto, ON M5T 1W7, Canada; adam.dmytriw@uhn.ca

Competing interests None declared.

Provenance and peer review Not commissioned; internally peer reviewed.

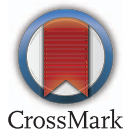

To cite Dmytriw AA. Med Humanit 2017;43:e23.

Published Online First 8 March 2017

Med Humanit 2017:43:e23. doi:10.1136/medhum-2017-011204 